Final version:

Lindgreen, A., Palmer, R., Vanhamme, J., and Wouters, J.P.M. (2006), “A relationshipmanagement assessment tool: questioning, identifying, and prioritizing critical aspects of customer relationships", Industrial Marketing Management, Vol. 35, No. 1, pp. 57-71. (ISSN 0019-8501)

For full article, please contact LindgreenA@ cardiff.ac.uk

\author{
A RELATIONSHIP-MANAGEMENT ASSESSMENT TOOL: \\ QUESTIONING, IDENTIFYING, AND PRIORITIZING CRITICAL ASPECTS OF \\ CUSTOMER RELATIONSHIPS
}

Adam Lindgreen, ${ }^{1,2}$ Eindhoven University of Technology

Roger Palmer, ${ }^{3}$ Cranfield School of Management

Joëlle Vanhamme, ${ }^{4}$ RSM Erasmus University

Joost Wouters, ${ }^{5}$ Eindhoven University of Technology

\footnotetext{
${ }^{1}$ Please address all correspondance to: Adam Lindgreen, Department of Organisation Science and Marketing, Faculty of Technology Management, TEMA 0.07, Eindhoven University of Technology, Den Dolech 2, P.O. Box 513, 5600 MB Eindhoven, the Netherlands. E-mail: a.lindgreen@tm.tue.nl. Telephone: + 31 (0) 402473700 . Fax: + 31 (0) 402468054.

2 The authors have been listed in alphabetical order.

${ }^{3}$ Roger Palmer, Cranfield School of Management, Cranfield University, Cranfield, Bedford, MK43 0AL, the UK. E-mail: r.a.palmer@cranfield.ac.uk. Telephone: + 44 - (0) 1234754 323. Fax: + 44 - (0) 1234751806.

${ }^{4}$ Joëlle Vanhamme, Department of Marketing, RSM Erasmus Univesity, Burg. Oudlaan 50, 3000 DR Rotterdam, the Netherlands. E-mail: jvanhamme@rsm.nl. Telephone: + 31 - (0) 10408 1194. Fax: + 31 - (0) 104089011.

${ }^{5}$ Joost Wouters, Department of Organisation Science and Marketing, Faculty of Technology Management, TEMA 0.10, Eindhoven University of Technology, Den Dolech 2, P.O. Box 513, 5600 MB Eindhoven, the Netherlands. Email: j.p.m.wouters@tm.tue.nl. Telephone: + 31 (0) 40247 2687. Fax: + 31 (0) 402468054.
} 
Page 2 of 54 


\section{BIOGRAPHICAL DATA}

Dr. Adam Lindgreen is an assistant professor of marketing with Eindhoven University of Technology. Adam Lindgreen received his PhD from Cranfield University. He has been a visiting professor with several universities including most recently Monash University, Melbourne University, and Georgia State University. Adam Lindgreen has published in Psychology \& Marketing, Industrial Marketing Management, Journal of Business Ethics, Journal of Marketing Management, and Journal of Customer Behaviour, among other journals. His research interests include relationship management, market orientation, purchasing, leadership, corporate social responsibility, and consumer behavior.

Dr. Roger Palmer is a senior lecturer of marketing with Cranfield School of Management. Roger Palmer received his $\mathrm{PhD}$ from Cranfield School of Management in 2001. He has published in Industrial Marketing Management, Journal of Marketing Management, and Qualitative Market Research, among other journals. Roger Palmer has substantial practical, industrial experience gained across different industry sectors. His research interests include business marketing, in particularly technology and product development, relationship and value management, and marketing strategy, implementation, and practice.

Dr. Joëlle Vanhamme is an assistant professor of marketing with RSM Erasmus University. Joëlle Vanhamme received her $\mathrm{PhD}$ from the Catholic University of Louvain. She has been a visiting scholar with several universities including the University of Auckland, Delft University of Technology, and Eindhoven University of Technology. Joëlle Vanhamme has published in 
Psychology \& Marketing, Journal of Economic Psychology, Recherche et Applications en Marketing, Journal of Marketing Management, and Journal of Customer Behaviour, among other journals. Her research interests include emotions, satisfaction/dissatisfaction, gift giving, and corporate social responsibility.

Dr. Joost Wouters is an assistant professor of marketing with Eindhoven University of Technology. Joost Wouters received his PhD from Eindhoven University of Technology in 2000. He teaches on marketing courses at Eindhoven University of Technology, as well as other Dutch universities. Joost Wouters has published in Industrial Marketing Management, among other journals. His research interests include customer service, market research, and the marketing of commodities. 


\section{TEASER}

Within the automotive industry, the article develops a practical tool to question, identify, and prioritize critical aspects of customer-relationship management. The tool encompasses customer relationships on a continuum from pure transactions to true relationships.

\section{ABSTRACT}

With customer-relationship management (CRM) no longer a buzzword among trendsetters, organizations in all types of industries initially rushed to embrace it. Although a seductively attractive concept, the implementation of CRM proved difficult, however, and organizations are struggling with realizing their vision of a CRM organization. To help managers assessing the stage of relationships between their organization and the organization's business customers we consider the automotive industry. Based upon our case organization and its relationships with numerous business customers we develop a practical tool to question, identify, and prioritize critical aspects of customer-relationship management. First, we identify key areas in CRM. Secondly, we investigate how the chosen case organization has managed each of these key CRM areas over a broad range of business-customer relationships. Thirdly, we acknowledge that many

organizations simultaneously have different types (transaction-relationship continuum) of business customers. We finish the article with a discussion of the study's limitations, and suggest avenues for future research. 
Keywords: Customer-relationship management; CRM; Relationships; Transactions; Assessment tool. 


\section{INTRODUCTION}

In the 1950s and 1960s, the challenge for businesses could largely be seen as putting in place the means of production to satisfy growing demand and, using marketing techniques to capture customers entering the market (e.g., Brookes \& Palmer 2004; Gummesson 1999; Parvatiyar \& Sheth 2000). Manufacturers of goods today, however, are competing in a very different environment, and transaction marketing (product, price, place, and promotion, the 4Ps) alone is believed to be insufficient (Denison \& McDonald 1995; Tapscott \& Caston 1993). Instead, relationship marketing is proposed for building more unique relationships with customers and for adding more value to goods and services than what is possible through transaction marketing (Grönroos 2000; Lindgreen \& Wynstra 2005). Relationship marketing, then, is not only about the 4Ps but also long-term relationships, reflecting a transaction-relationship continuum (Webster 1992). Whereas the literature has investigated the theoretical development of relationship marketing, to our knowledge it has been silent on how to assess the management of relationships between an organization and its business customers. This is despite the fact that such a tool would be of great managerial interest to practitioners, for example by providing a valuable platform for managers to further advance and improve on relationship marketing. Reporting how one organization practically developed a tool for assessing its relationship-management activities, our article addresses this gap in the literature.

The remainder of the article is organized as follows. First, the literature on relationship

management is reviewed, identifying key areas. Subsequently, the managerial implementation of these areas is investigated through in-depth interviews with key informants from our case 
organization. Then the findings, in the form of the relationship-management assessment tool, are discussed and the study's managerial implications are considered. The article finishes with a discussion of the limitations to the research, and suggests avenues for future research.

\section{MANAGING CUSTOMER RELATIONSHIPS}

At the center of relationship management is the concept that customers, because of their purchasing of goods and services, provide organizations with an income. The focus, therefore, is on both the long-term relationship and the short-term transaction (Gummesson 1996). Often the profitability of long-term relationships is higher than that of individual and discrete transactions (Dowling \& Uncles 1997; Reichheld 1996), although this is not always so (e.g., Reinartz \& Kumar 2002).

Reviewing how CRM has been advanced in the literature, Zablah, Bellenger, \& Johnston (2004a) note that conceptualizations of CRM have defined it as a process, strategy, philosophy, capability, or a technological tool. Each conceptualization, the authors contend (p. 281), "contributes in unique ways to the understanding of this phenomenon [CRM]". An early definition of relationship marketing is provided by Grönroos (1990: p. 7), "The role of relationship marketing is to identify, establish, maintain and enhance relationships with customers and other stakeholders, at a profit, so that the objectives of all other parties involved are met; and that this is done by a mutual exchange and fulfillment of promises". CRM, when applied to Grönroos's definition, is the management of relationship marketing applied to (a business's) customers (Lindgreen 2004). This is in agreement with Zablah, Bellenger, \& 
Johnston (2004b) who define the purpose of CRM as "building and maintaining a profitmaximizing portfolio of customer relationships" (p. 480).

Explanations of how and why many business-to-business relationships evolve over time have been proposed by various authors (e.g., Dabholkar, Johnston, \& Cathey 1994; Dwyer, Schurr, \& Oh 1987; Hunt 2000). For example, Dwyer, Schurr, \& Oh (1987) proposed that buyer and seller interactions are not discrete and independent of one another but interact with time. Developing further the concept of relationship evolution, Millman \& Wilson (1994) presented a relational development model that demonstrated the progression of relationships from transactional to relational, demonstrating increasing levels of customer involvement to the extent that shared information, joint working, and mutual commitment to projects and processes is achieved at the relational level. Various stages of relationships can be identified, each of which demonstrates identifiable characteristics. This has been further expanded by McDonald, Rogers, \& Woodburn (2000). Again, it should be appreciated that not all relationships develop into relational ones but stay transactional thus reflecting a continuum of customer relationships (Webster 1992).

Hence, there is a firm conceptual basis on which relationship development can be understood, and as such operationalized via CRM programs. Actively managing relationships to achieve a desired transactional/relational state is problematic, however, and between 35 and 75 percent of CRM programs fail (Rigby, Reichheld, \& Schefter 2002; Zablah, Bellenger, \& Johnston 2004a). Also, programs not only fail to deliver in economic terms, but also damage the organization's relationships with its customers. Managers therefore have come to give a low priority to CRM programs (Rigby, Reichheld, \& Schefter 2002). 
The reasons for program failure proposed by Rigby, Reichheld, \& Schefter (2002) suggest that companies are prone to making unquestioned assumptions and building on implicit beliefs. Planning and managing positive interventions in turn becomes problematic. If assumptions and beliefs can be made explicit and questioned, however, then this would suggest that more relationship-management strategies can be developed. This in turn may have implications for the underpinning culture, attitude, and values of the organization, as it works to develop relationshipmanagement strategies.

As a result the management of customer relationships becomes one of the single most critical issues. As has been discussed, relationships with customers typically change in character as they develop. For example, long-term relationships demonstrate a higher degree of cooperation and collaboration between an organization and its customers, and the parties are more dependent upon each other (e.g., Ford 1990). To achieve relationship benefits an organization needs to know its customers (Sheth \& Parvatiyar 2002). A tool to assist in assessing the management of customer relationships is therefore particularly important, especially when these are changing from one state to another.

Our approach, when seeking to identify the key elements of relationship management, is to address the leading schools of thought (c.f.: Brodie, et al. 1997; Sheth \& Parvatiyar 2000). This includes the Industrial Marketing and Purchasing group (e.g., Ford 1990), the Nordic school (e.g., Gummesson, Lehtinen, \& Grönroos 1997), and the Anglo-Australian approach (Payne 1995). Table 1 provides an overview of the main components of each of these schools. The 
elements are reported in the methodology. The purpose of the relationship-management tool is to make explicit and to help managers to question, identify, and prioritize critical aspects of customer relationships (transactional/relational), and to shift between different relationship types.

\{Place Table 1 About Here\}

\section{METHODOLOGY}

We chose to examine the automotive industry that is global in scale, remains a major contributor to national economies, and together with its network of suppliers provides leading examples of relationship development and practice. Buyers of vehicles are increasingly demanding, and manufacturers are under pressure to bring out new and innovative models with greater levels of individuality. As a result, original equipment manufacturers are looking to suppliers to bring these attributes to their goods (Beecham 2001; Pine 1993). Supply arrangements can often be secured by building cooperative and collaborative relationships levering new goods and key technologies. Toyota, for example, demonstrates its ability to build and manage a network of relationships producing goods of high quality delivering enviable levels of reliability and satisfaction (Kotler 2003). The automotive industry, in short, is often taken as a bellwether for manufacturing, and in Western Europe currently one third of manufacturing capacity is not utilized (Brookes \& Palmer 2004; Kotler 2003). Building and effectively managing relationships by offering personalized goods and services is therefore essential. 
More in particular, we examined one case organization, the name of which has been suppressed for confidentiality reasons. Although this organization defined and executed its relationshipmanagement strategy it proved difficult for the organization to assess the current status of its relationship-management activities. The use of qualitative methods is appropriate when the aim is to study complex processes (Eisenhardt 1989; Yin 1994). A single-case approach was chosen due to the complex nature of relationship management and its practical implementation. This required that a large number of variables would be taken into account in order to describe how relationship management was being managed. Despite criticism that such a process may result in only surface-level insights (Dyer \& Watkins 1991; Weick 1979), the use of secondary data and multiple interviews in the case helped develop rich insights and also provides the basis for greater transferability of the findings to other contexts (Eisenhardt 1991). Also, in order to reduce the negative effects of what Easton (1995: page 379) terms 'quasi-deductive theory testing', that is partial support of a theory, we conducted a comprehensive literature review to identify elements pertaining to relationship management.

The organization of these elements into 10 different key areas helped to guide us when finding codes, themes, and patterns in the interview transcripts (Dubois \& Gadde 2002). Lastly, it should be appreciated that although the article reports on a single case organization the codes, themes, and patterns, which we identified from the mapping of 60 customer-contact points, are the results of analyzing how this organization manages its exchange relationships with different types of many business customers (i.e., car makers, wholesalers, retailers, importers, distributors, and dealers), from pure transactional to pure relational. Within this case study, therefore, it was possible to compare and contrast relationships with regard to how successfully they had been 
implemented. Also, some had been customers for a longer time than others. The case organization also kept archival records of past customers, with information on satisfaction levels and complaints, among other things. This provided an opportunity to examine exchange relationships that had not been successful or relationships in term of duration.

The case organization, with its headquarters and technology development center in Northern Europe but operating globally, was selected because of its high perceived successes. The organization operates in a highly competitive business-to-business environment and is one of the world's leading suppliers of lighting solutions for vehicles, seeking to become the number one supplier in lighting solutions to the automotive industry. Also the simplicity of the case's competitive scenario and strategic response, relative to larger, more complex manufacturers, made this case attractive. Lastly, the organization's relationship-management program had largely been developed and implemented, and an assessment of how it was being managed was needed. For example, although the most recent customer satisfaction survey shows that the organization is performing adequately its customers do not perceive the organization as a preferred supplier. This presents important challenges for the organization.

Lee \& Quazi (2001) provide a generic methodology for developing a self-assessment tool. For the purposes of our study, the methodology ensures that the essential attributes of the relationship-management assessment tool will not be excluded during the design state. The methodology contains the following attributes: the development of relationship-management elements and the scoring system. The focus is on the identification of the relevant relationshipmanagement elements and, per element, the development of an appropriate scoring system. To 
do so an interpretative research approach was used (Klein \& Meyers 1999). Since the boundaries of the relationship-management elements were not clearly evident at the outset of the research, the study involved a contemporary set of analyses over which no experimental control or manipulation was used (Benbasat, Goldstein, \& Mead 1987). One of the main benefits of this method, according to Miles \& Huberman (1994), is that researchers can move to probing questions relating to 'how' and 'why' type questions. These questions deal with operational links that may need to be traced over time, rather than relying on mere frequencies or incidents.

Based on a literature review (see shortly) a primary checklist was assembled containing relevant issues pertaining to relationship management. Following that, in-depth interviews were conducted with key informants within the focal business group of the organization, as well as with key figures from other business groups of the organization. Seven interviews were held in all, each lasting an average of three hours. All interviews were taped and transcribed. This allowed for a more thorough analysis. The same interviewer conducted all the interviews in order to reduce the likelihood of bias (Lincoln \& Guba 1985; Strauss \& Corbin 1998).

The volume of data was condensed through coding and memoing and by finding themes, clusters, and patterns (Miles \& Huberman 1994). Additional material and evidence was brought in using appropriate literature and company documents (e.g., ISO handbook and customer satisfaction surveys). Also, a customer touch-point analysis was made identifying all the customer-contact points in time and throughout the organization, approximately 60 in all. Touchpoint communication and information flows were mapped. The management of all of these touch points was analyzed and discussed with key informants. Following this, an initial report was 
written and sent to each interviewee for review and feedback, which was incorporated into the final analysis. This method reinforced reliability of the findings.

The process described above, and the use of multiple sources of evidence, helped improve the validity of the research (Yin 1994). Eventually a list of 10 relationship-management elements was obtained, as well as an extensive list of scale items per element. The number of relationshipmanagement elements was not predetermined, but resulted from the data analysis. Following that, the key informants did a systematic ranking of the scale items, with a cumulative scale construction per element. The interviewer and two industry experts performed the similar task. Following that, the results were grouped and analyzed. Discrepancies were discussed until consensus was achieved. The number of scale levels per element was determined in advance to match with other tools used within the case organization. 11 scale levels per element in all are distinguished ranging from 0 to 10 . From experience this number of levels provides an optimum regarding sufficient detail and meaningful interpretations of the levels. In the subsequent analysis step, per element, the scale items referring to a maximal and minimal score were determined. The level 0 represents a minimum level and would indicate an immature and non-sophisticated relationship-management structure, whereas level 10 represents a maximum and indicates a situation with a mature and well-managed relationship-management program. Again, it should be appreciated that 'high-level' relationships are not always the best interaction design. This will be discussed in more details in the section on managerial implications.

Next, several intermediate scores (between 0 and 10) were determined. All items were ranked systematically with the cumulative scale construction. Key informants were presented with a 
sorting task in which the items were listed on separate cards to be sorted based upon maturity and sophistication within each element. Informants were asked to do the sorting randomly in ascending or descending order. Again, the interviewer and two industry experts performed the similar task. Also, following that, the results were grouped and analyzed. Discrepancies were discussed until consensus was achieved. When necessary the position of some items was estimated. During this procedure some items were deleted altogether.

The iterative rounds of involvement and reflection, with the interviewer and two industry experts involved as researchers as well as participants in the phenomenon under review (i.e., the evolving nature of key CRM elements of the assessment tool), reflects an action-research approach (Lewin 1946), where the purpose is for "a group of people [to] work together to improve their work processes" (Carson et al. 2001: p. 158; see also the special issue of European Journal of Marketing 2004, edited by Chad Perry)", with 'work processes' being the relationshipmanagement assessment tool in this case. Action research is particularly useful as a methodology when the perception of variance is strong between how a phenomenon has been conceptualized at a general level and how the practice of said phenomenon is approached pragmatically (Carson et al. 2001).

The whole approach is depicted in Figure 1. The entire procedure was conducted iteratively, consulting the original interviewees and, as previously indicated, industry experts throughout. Ultimately, a draft version of the relationship-management assessment tool was presented to the key informants, and final comments were given and incorporated in the assessment tool. 
\{Place Figure 1 About Here\}

\section{FINDINGS}

A brief discussion will be presented for each of the relationship-management elements. Following this, using the outcomes for one of the elements (customer strategy), the process of scale development is illustrated. The same approach as described above was adhered to for the other elements of the tool. The resulting 10 scales have been included as Appendix A.

\section{Element 1: Customer Strategy}

If a customer strategy is not created prior to implementation of the relationship-management program there is a real risk that managing the program will fail (Brown \& Gulycz 2002; Rigby, Reichheld, \& Schefter 2002). A customer strategy focuses on how to attract new customers, and how to maintain and develop relationships with existing valuable customers (Christopher, Payne, \& Ballantyne 1991; Grönroos 1994; Jackson 1985). When a customer strategy builds trust and commitment it drives the growth in the organization's profitability (Grönroos 2000; Morgan \& Hunt 1994). Managing relationships requires that the most profitable customers are identified (Kenyon \& Vakola 2001). This means that effective relationship management is based on traditional customer-segmentation analysis (Rigby, Reichheld, \& Schefter 2002). Segments, in turn, are based on the lifetime-value of customers for which qualitative or quantitative objectives are set (Ryals \& Knox 2001; Zikmund, McLeod, \& Gilbert 2003). The lifetime-value is an estimate of the net present value of the stream of benefits from a particular customer less the 
burdens of servicing the account or managing the relationship (Dwyer \& Tanner 2002). To meet the objectives set by the program, segment-specific treatments have to be developed and must be executed for each customer in a customized way. The customer segmentation process should therefore take place in two stages, first rank the customers by their value and then differentiate them by their specific needs (Brown 2000). The more an organization can break down its valuable customers into different groups with different needs and expectations the better it can serve them (Day 2003). Retaining the most valuable customers will increase the organization's profitability (Lindgreen \& Crawford 1999; Reichheld 1996).

\section{Element 2: Customer-interaction Strategy}

Once the organization has identified the customers with whom it wishes to have a durable relationship, there are a number of ways to interact with them. Customer interaction refers to how an organization interacts with its customers and how it delivers goods and services to them (Brown \& Gulycz 2002). This includes all the interaction processes, touch points, employees, and distribution channels. The purpose is to get to know when and how customers want to interact with the organization (Prahalad \& Ramaswamy 2001; Woodcock, Stone, \& Foss 2003). All interactions during the customer lifecycle must be well coordinated and customized through all touch points. This must be in relation to the customer's individual profile that has been developed by using data gathered from past contacts. All touch points must be effectively and cost-efficiently used to distribute various goods and services and to communicate with customers (Peppers \& Rogers 1997). This implies that interaction with low value for customers should take

place through low-cost channels. Also, customer interactions must be well coordinated and 
managed across all functions and levels in the organization (Ford 1980). Indeed, delegating responsibility and empowering staff to handle customer contacts is essential for relationship management (Eriksson \& Mattson 2002). The interaction strategy should be developed so all channels create synergy and a competitive advantage (Peppers \& Rogers 1997).

\section{Element 3: Brand Strategy}

Brands are a major determining element in the repeat purchase of an organization's goods and services (Christopher, Payne, \& Ballantyne 1991; Lederer \& Hill 2001). Successful brands achieve higher levels of customer loyalty (Doyle 1989; Masters 2000; Zikmund, McLeod, \& Gilbert 2003). The brand strategy describes what an organization's brand stands for, who it wants to be, and how to act to achieve that identity. The strategy positions the brand as perceived by customers and shareholders to occupy defensible positions in various marketplaces. Mitchell, King, \& Reast (2001) found that in an industrial setting branding generates more confidence in the purchase decision, enhances corporate reputation, and offers more scope for competitive advantage thus creating barriers for competitive entry. A strong brand makes an organization more attractive and creates a relationship of trust with external and internal stakeholders thus strengthening the organization's market position (Doyle 2000; Hart \& Murphy 1998).

\section{Element 4: Value-creation Strategy}

Relationship management is a value-adding activity through mutual interdependence and collaboration between an organization and its customers and other stakeholders (Sheth \& 
Parvatiyar 2002). Value creation is the main purpose of the existence of these relationships and must be seen as a condition for defining marketing strategies (Anderson \& Narus 1999). Any strategy must focus on creating value for both the organization and its stakeholders (Hamel \& Prahalad 1994; Wilson, Daniel, \& McDonald 2002). It should provide answers to questions like: how to create and deliver value to customers, and how to maximize customer lifetime value in order to increase customer profitability. A well-defined value-creation strategy offers superior value to individual customers, and at the same time maximizes profitability from each relationship. Delivering superior value to customers will strengthen the organization's competitive advantage and it becomes difficult, if not impossible, for competitors to copy this capability (Day \& Wensley 1988; Doyle 2000; Kothandaraman \& Wilson 2001). Various approaches are presented in the literature that try to capture the sophistication of the valuecreation process (e.g., Evans \& Berman 2001) or seek to identify the value drivers in relationships (e.g., Beverland \& Lockshin 2003; Ulaga 2003).

\section{Element 5: Culture}

Relationship management requires a strategic change from a product or process-focused culture towards a customer-focused culture (Christopher, Payne, \& Ballantyne 1991; Peck 1995; Ryals \& Knox 2001). Organizational culture is operationalized as "the pattern of shared values and beliefs that help individuals understand organizational functioning and thus provide them with the norms for behavior" (Deshpandé \& Webster 1989). Culture is perhaps the most important element in successfully managing the implementation of a relationship-management strategy (Rigby, Reichheld, \& Schefter 2002). To meet customer expectations it is necessary to develop a 
culture that is customer oriented. A change in employee attitude to businesses is often inevitable. Customer orientation is a type of organizational culture and it makes organizations more responsive to customer needs (Deshpandé \& Webster 1989). Furthermore, a customer-oriented culture is essential for the quality and extension of customer-knowledge creation and dissemination (Tozkas \& Saren 2004), which in turn is a pivotal concept in relationship marketing (see also element 10). It has been contended that a customer-oriented culture positively affects customer satisfaction (Conrad, Brown, \& Harmon 1997; Deshpandé, Farley, \& Webster 1993). Every department in an organization should realize that customer satisfaction is a component for building strong relationships, and that this depends on the delivered quality of the value-added goods or services (Kenyon \& Vakola 2001; Woodcock, Stone, \& Foss 2003).

\section{Element 6: People}

People are indispensable in every organization. They are the ones who manage business issues, communicate throughout the organization, and build relationships with customers (Christopher, Payne, \& Ballantyne 1991). Some argue that they are the most important asset an organization can have (Berry 1986; Reichheld \& Kenny 1990). All employees in the organization must understand their roles and meet required skills and orientation defined in recruiting programs (Brown \& Gulycz 2002; Georgiadis \& Lane 2001). To achieve excellent business performances and relationships with valuable customers, the organization must have knowledgeable, skilful, and motivated employees and teams. Employees should have market sensing and an ability to

understand customers. Also, they must be able to gain their customers' trust and respect. Tellefsen \& Thomas (2004) demonstrated that within service firms a representative's personal 
expertise and power within the organization increase personal commitment and, as personal commitment increases, relational exchange increases. Often employees are required to demonstrate appropriate leadership (Day 2003; Georgiadis \& Lane 2001). To retain valuable employees they must receive recognition and be rewarded for their performance and customerfocused behavior (Clark \& Payne 1995; Woodcock, Stone, \& Foss 2003). Employee satisfaction has a positive impact on customer retention (Reichheld 1996; Reichheld \& Sasser 1990).

\section{Element 7: Organization}

Understanding the organization is important for succeeding with relationship management (Brown \& Gulycz 2002). Organizational structure affects the performance of all the organization's activities. The key principles involved in relationship management are gathering, coordinating, and analyzing accurate data on customers, developing marketing strategies that personalize the relationship, and maximizing the value to the organization by focusing on highervalue customers. Customer-centric organizations will not only integrate the sales, marketing, and customer service functions but also non-marketing functions (Sheth, Sisodia, \& Sharma 2000). This calls for a high degree of cross-functional collaboration to provide customers with a high service level (Clark, Peck, Payne, \& Christopher 1995; Ryals \& Knox 2001). Internal communications must work seamlessly and smoothly among customer-facing employees and between them and the rest of the organization. Managing a relationship-management program requires commitment from top management, and different departments must work closely together to maximize return on customer information (Foss \& Stone 2001). This again will require well-defined policies and procedures. Cross-functional collaborations create enthusiasm, 
accelerate processes, and facilitate implementations of activities. Besides this, the whole organization must possess a flexible character to support customer-oriented decision-making and should have the flexibility to anticipate and respond to customer requests (Grönroos 2000).

\section{Element 8: Information Technology}

The role of information-technology tools in relationship management is to facilitate the different customer processes, such as segmentation of customers based on their value or prediction of customer behavior (Clark \& Smith 2003; Gummesson 2002; Ryals \& Knox 2001). To support these processes a well-organized information-technology infrastructure and architecture is needed to communicate effectively through the whole organization (Zikmund, McLeod, \& Gilbert 2003). Also, information-technology system tools and data warehouses must be accessible to all employees to allow them to analyze customer data accurately, including analyzing customers' purchasing behavior (Woodcock, Stone, \& Foss 2003). Importantly, organizations must have prioritized their analytical needs before making major investments in information technology (Gartner Group 2003; Kracklauer, Mills, \& Seifert 2003). Lastly, all technology selections must have been validated by customer-oriented processes (Peppers \& Rogers 1997). Campbell (2003) found that organizations often spent more effort on generating customer knowledge than on integrating this knowledge in their core processes.

The information-technology architecture determines which information systems support and manage business processes, and how information systems interact with each other. This includes front-office applications and back-office systems. Integration of enterprise resource-planning 
systems is necessary to support business processes effectively (Brown \& Gulycz 2002). By integrating and synchronizing the customer-information flows of the different information systems and touch points, communication and collaboration between departments are eased. Rationalization of the organization's data can lead to greater operational efficiency by avoiding the high costs of maintaining different information systems with redundant data (Sawhney 2001). Information-technology systems tools (e.g., data mining tools) allow organizations to analyze information and identify unseen patterns or trends in markets and purchase behavior of customers (Brown \& Gulycz 2002; Rigby, Reichheld, \& Schefter 2002). It helps to gather and analyze information derived from different locations. This analysis of information may be used to provide customized communications and goods offerings.

\section{Element 9: Relationship-management Processes}

Monitoring of relationship-management processes like complaint management or service management is an important activity to meet the objectives of the organization and improve relationships. Processes should be built, mapped, and understood to realize process improvements (Brown \& Gulycz 2002; Woodcock, Stone, \& Foss 2003). Management of processes involves the procedures, task schedules, mechanisms, activities, and routines by which a product or service is delivered to the customer (Christopher, Payne, \& Ballantyne 1991). Organizations must set measurable, specific relationship-marketing objectives, and key performance indicators (e.g. retention rate, share of wallet, customer lifetime value, and customer satisfaction) Formal feedback and formal evaluation of relationship-management strategies and processes are important for continuous improvement (Brown \& Gulycz 2002). The 
strategic and business processes must produce clear objectives for improvements, and have a strong focus on customer satisfaction (Pine, Victor, \& Boynton 1993). Also, processes need to be reviewed regularly for acceptability from both the customers' and the organization's perspective (Woodcock, Stone, \& Foss 2003).

\section{Element 10: Knowledge Management and Learning}

Knowledge management implies the facilitation of knowledge creation, knowledge sharing, and knowledge application processes (Grotenhuis \& Weggeman 2002). To adapt the organization to the fast-changing environment, creating and sharing of knowledge is needed (Ballantyne 2000). When the business processes become highly knowledge-intensive an organization's long-term success and growth is dependent on the management of its corporate knowledge across its business processes (Bose \& Sugumaran 2003). True relationship management is said only to be possible when knowledge management is integrated, with data being transformed into knowledge (Bose \& Sugumaran 2003). The availability of appropriate knowledge is an essential component for the development of strategies, goods, and services, as well as distribution channels and communication channels to customers. Knowledge about customer behavior and employees' knowledge on, for example, sales practices and business processes are examples of knowledge resources. It is important that organizations are resourced in such a way that exchange of knowledge is stimulated (Zikmund, McLeod, \& Gilbert 2003). This can be facilitated by appropriate information-technology systems. Employees can learn from each other through exchange of knowledge and best practices. Furthermore, training and education are necessary for development of employees' knowledge, which affect the learning capabilities of the 
organization. Several authors (e.g., Sinkula, Baker, \& Noordewier 1997; Tozkas \& Saren 2004) offer frameworks for knowledge generation and management.

\section{Assessment-tool Development}

We move on to describe how the scale was developed for element 1 . First, the literature review and the subsequent in-depth interviews with key informants from different business groups resulted in a list of stages in the relationship between the organization and its business customers. In the subsequent prioritization of these items their wording would be discussed further with the key informants and, if necessary, refined to reflect the customer-relationship stages. Disagreements would be resolved by bringing together the key informants and three experts on CRM who would reach consensus. The experts were not part of the case organization.

In the next step we characterized the minimum and maximum levels of relationship-management stages. The customer strategy, at the lowest level, is simplistic and lacks any criteria by which to select customers. The organization sells goods to customers willing to buy. At the highest level, however, the customer strategy is sophisticated and drives the growth in the organization's profitability. Also, trust and commitment are built, which means that the organization and its customers are prepared to exchange knowledge with each other. Note the following two levels:

Level 0: We sell our goods to customers who are willing to buy. We have no criteria in place to select customers.

Level 10: We develop excellent customer strategies, which create customer trust and commitment, and drive the growth in our profitability. We are the number one strategic supplier of our most valuable customers. 
In order to develop the most value-adding goods and services in the marketplace we collaborate closely with our customers to exchange knowledge.

These two extreme levels were relatively easy to determine. It was more challenging to determine the intermediate levels that had to be ranked over nine levels. Segmentation based on the life-time values of individual customers was a central issue for the customer-strategy element. This item was therefore positioned on level 5. Note the following level:

Level 5: We rank customers by their value in order to define customer segments. Customers with similar lifetime value are allocated to the same customer segment.

For ranking of the remaining items we worked forwards from lower levels to higher levels to avoid errors of ranking. Items were ranked systematically in a cumulative manner, which led to the final levels of the scale. Note the following levels:

Level 1: We have a customer strategy to select customers. Someone in our organization is responsible for this strategy.

Level 2: We define customer strategies, which are mainly focused on acquiring new customers.

Level 3: We base our customer strategies primarily on the needs of prospective and existing customers, rather than on (potential) customer-lifetime value.

Level 4: We analyze the lifetime value of individual customers to understand their importance to our organization. Different approaches including for example activity-based costing are used to calculate the value of individual customers.

Level 6: We set clear business objectives for each customer segment. We develop a corresponding value proposition that is consistent with these objectives including, for example, a selling and pricing strategy. In each segment customers have the same lifetime value, but are differentiated from each other by their needs. 
Level 7: We build and develop relationships with our most valuable customers. We continually analyze their potential, and we take actions to transform unprofitable customers into profitable ones.

Level 8: We retain our most valuable customers by understanding loyalty drivers and by introducing appropriate value-adding propositions. Moreover, we know why some customers defect and how to win these customers back. We increase our customer retention by offering value-adding propositions.

Level 9: We meet the specific needs of our customers, and our value propositions regularly exceed their expectations. We build unique relationships with our most valuable customers. Our customers prefer our organization to do business with rather than our direct competitors because we excel in creating valueadding opportunities. We review our customer strategy continually.

\section{MANAGERIAL IMPLICATIONS}

The relationship-management assessment tool provides a means by which the implementation of a CRM program can be analyzed. The case organization has adopted the assessment tool with alacrity and demonstrated the strategic role of such a tool in their specific context. Each organization will have different approaches as to how they wish to manage and report on strategic implementation. For example, the assessment tool could be adapted as a form of scorecard, expressed visually as a radar diagram, and also lends itself to presentation in electronic format in a variety of ways. In whatever format this would provide a simple and easily accessible means of monitoring the implementation of a relationship-management program. The tool could be leveraged further by agreeing target levels of achievement by segment. The gap between actual and target then forms the basis for a focused discussion as to how the gap is to be filled. Similarly, over achievement against target leads to a discussion as to whether or not there is over provision of resource that might be more usefully allocated elsewhere. 
The assessment tool also provides a means whereby cross comparisons can be made on an organization basis. This would provide a comfortable fit with an extension to more formalized planning processes such as the 10-step marketing planning process (McDonald 2004), which gives comprehensive guidance on strategy development, but less detail with regard to the monitoring of implementation. Again, at the organization level there is the opportunity to link the assessment tool to other measures in order to give more comprehensive relevant summary of performance and the interim process steps.

\section{Transactions or Relationships? Or Transactions and Relationships}

Not all business customers necessarily want or require a relationship, hence a portfolio of business customers requires a range of CRM solutions. Authors on service marketing including Garbarino \& Johnson (1999), Anderson \& Narus (1999), and Coviello, et al. (2002) supported the proposition that what takes place is one of co-existence of transactional and relational relationships rather than the application of one or the other. For example, early work by Jackson (1985) suggests that buyer/supplier relationships can be considered as spanning a continuum from transactional to relational with suppliers occupying a position along that continuum (see also Webster 1992). The suppliers should recognize and interpret the interaction style of the buyer and adapt their own behavior accordingly (Boorom, Goolsby, \& Ramsey 1998; Comstock \& Higgins 1997). Also, what the 'Contemporary Marketing Practice' research group has found is that different types of organizations have different types of practices, and some organizations adopt multiple styles of relationships to their business customers (see, for example, Brookes \& Palmer 2004). Also, Beverland \& Lindgreen (2004) identified a relationship between changes in 
market dynamism and the form and intensity of business exchange relationships. Organizations routinely form, build upon, and exit out of relationships in response to a changing environment and changing strategic needs. The debate should not be about whether to emphasize or deemphasize relationships under certain conditions (Achrol \& Etzel 2003; Joshi \& Campbell 2003), but should rather focus on which business relationships to invest in further or divest oneself of, and which business relationships to keep on a transactional level.

Anderson \& Narus (1999) discuss the concept of the relationship continuum. This may provide some explanation for the above findings. Rather than proposing a continuous or incremental change in the nature of relationships from purely transactional to purely collaborative, these authors propose that a range of relationships, which are more or less transactional or collaborative, varying around the marketplace norm, characterize marketplaces. They refer to this as the industry bandwidth, and propose that different industries can occupy different bandwidths along the transactional/collaborative continuum. Within an industry implicit understandings will develop as to the nature of customers and the appropriate level of relationship. The reasons for program failure proposed by Rigby, Reichheld, \& Schefter (2002) suggest that companies are prone to making unquestioned assumptions and building on implicit beliefs. If assumptions and beliefs can be made explicit and questioned then this would suggest that more considered relationship-management strategies can be developed. This in turn may have implications for the underpinning culture, attitude, and values of the organization, as it works to develop relationship strategies that stretch bandwidth beyond the industry norms. Our relationship-management helps managers to question, identify, and prioritize critical aspects of relationships in order to move beyond the industry bandwidth. 


\section{CONCLUSIONS}

The concept of CRM is still diffuse. Our study contributes to our understanding of the concept by providing a framework that makes CRM a more 'tangible currency'. It can lead the discussion to what relationship management should do rather than what it consists of, and therefore acknowledge its contribution to strategy and organization performance. For the case organization a study was conducted to develop a relationship-management assessment tool. The objective was to develop a tool for assessing and further improving the organization's capabilities regarding relationship management. Using an interpretative approach, which included in-depth interviews, additional evidence, and feedback loops, 10 relationship-management elements, covering the full scope of relationship management, were identified. Subsequently, 11 point scales were worded for each element. An assessment of an organization's current position regarding relationship management is a valuable platform for managers to further advance and improve on relationship management. Also, it can provide a useful format for creating more customer value. In this way we hope to have moved from the concepts of relationship management to the managerial realities of relationship management.

A limitation of our study can be found in the single-organization approach. Although information was obtained from a business group other than the focal business group with which we conducted in-depth interviews it still reflects the same organizational culture. Follow-up studies are also required covering a different range of organizations, for example those offering different goods and services. Also, although the identification of the 10 relationship-management 
elements were identified from interviews with the case organization and from reviewing the literature we realize that there is some overlap between the different elements. For example, surveys of additional case organizations would help to establish which elements are common across all types of organizations, and which elements are specific to particular organizations. We also acknowledge that since we undertook our research other studies in a similar way have identified critical success factors of CRM, including for example Zablah, Bellenger, \& Johnston (2004a). Such studies should obviously be consulted in any future research. Lastly, customer input was only indirectly achieved through customer satisfaction surveys and customer touchpoint analysis. Obtaining direct customer input, particularly on the items, could increase the tool's validity.

The various limitations can be addressed by replicating the study in different organizational contexts and developing further the linkages between strategy development, implementation, and performance measurement. There is also the opportunity to further refine the assessment tool and the number of scale points. The extensive criteria could be abstracted further to increase the focus of managerial attention and ease of use. Lastly, the value of the tool will only become apparent when it can be linked with desired organizational outcomes. Therefore it is important to link the tool to outcome variables like customer satisfaction, customer loyalty, and customer retention, as well as financial performance indicators like profits and acquisitions costs.

\section{ACKNOWLEDGMENTS}


Thanks to the reviewers, the editor, and Michael Antioco for their constructive feedback on previous drafts of this article. Also thanks to the case organization for its cooperation. Thanks to Mr. Chun $\mathrm{Wu}$ for assistance in data collection.

\section{REFERENCES}

Achrol, R. S. \& Etzel, M. J. (2003), "The structure of reseller goals and performance in marketing channels", Journal of the Academy of Marketing Science, Vol. 31, No. 2, pp. 146163.

Anderson, J. \& Narus, J. (1999), Business Market Management, Prentice Hall, Sydney.

Ballantyne, D. (2000), "Internal relationship marketing: a strategy for knowledge renewal", International Journal of Bank Marketing, Vol.18, No. 6, pp. 274-286.

Beecham, M. (2001), Global Market for Automotive Lighting Equipment, Philips, Eindhoven.

Benbasat, I. G., Goldstein, D. K., \& Mead, M. (1987), "The case research strategy in studies of information systems", Management Information Systems Quarterly, Vol. 11, No. 3, pp. 369386.

Berry, L. L. (1986), "Big ideas in services marketing", Journal of Consumer Marketing, Vol. 3 , No.2, pp. 5-9.

Beverland, M. \& Lindgreen, A. (2004), "Relationship use and market dynamism: a model of relationship evolution", Journal of Marketing Management, Vol. 20, No. 7-8, pp. 825-858.

Beverland, M. B. \& Lockshin, L. S. (2003), "A longitudinal study of customers' desired value change in business-to-business markets", Industrial Marketing Management, Vol. 31, No. 8, pp. 653-666. 
Boorom, M., Goolsby, J. R., \& Ramsey R. (1998), "Relational communication traits and their effect on adaptiveness and sales performance", Journal of the Academy of Marketing Science, Vol. 26, No. 1, pp. 16-30.

Bose, R. \& Sugumaran, V. (2003), "Application of knowledge management technology in customer relationship management", Knowledge and Process Management, Vol. 10, No. 1, pp. 3-17.

Brodie, R. J., Coviello, N. E., Brookes, R. W., \& Little, V. (1997), "Towards a paradigm shift in marketing? An examination of current marketing practices", Journal of Marketing Management, Vol. 13, No. 5, pp. 383-406.

Brookes, R. \& Palmer, R.A. (2004), The New Global Marketing Reality, Palgrave, Basingstoke.

Brown, S. A. (2000), Customer Relationship Management, John Wiley \& Sons, Toronto.

Brown, S. A. \& Gulycz, M. (2002), Performance-driven CRM, John Wiley \& Sons, Toronto.

Campbell, A. J. (2003), "Creating customer knowledge competence: managing customer relationship management programs strategically", Industrial Marketing Management, Vol. 32, No. 5, pp. 375-383.

Carson, D., Gilmore, A., Perry, C., \& Grønhaug, K. (2001), Qualitative Marketing Research, Sage Publications, Thousand Oaks, California.

Christopher, M., Payne, A., \& Ballantyne, D. (1991), Relationship Marketing, ButterworthHeinemann, Oxford.

Clark, M. \& Payne, A. (1995), "Achieving long-term customer loyalty: a strategic approach", in Payne, A. (Ed.), Advances in Relationship Marketing, Kogan Page, London, pp. 53-63. 
Clark, M., Peck, H., Payne, A., \& Christopher, M. (1995), "Relationship marketing: towards a new paradigm", in Payne, A. (Ed.), Advances in Relationship Marketing, Kogan Page, London, pp. 263-278.

Clark, M. \& Smith, B. (2003), "Building the foundations for effective CRM", Management Focus, No. 20, pp. 15-17.

Comstock, J. \& Higgins, G. (1997), "Appropriate relational messages in direct selling interaction: should salespeople adapt to buyers' communicator style", Journal of Business Communication, Vol. 34, No. 4, pp. 401-418.

Conrad, C. A., Brown, G., \& Harmon, H. A. (1997), "Customer satisfaction and corporate culture: a profile deviation analysis of a relationship marketing outcome", Psychology \& Marketing, Vol. 14, No. 7, pp. 663-674.

Coviello, N. E., Brodie, R. J., Danaher, P. J., \& Johnston, W. J. (2002), "How firms relate to their markets: an empirical examination of contemporary marketing practices", Journal of Marketing, Vol. 66, No. 3, pp. 33-46.

Dabholkar, P. A., Johnston, W. J., \& Cathey, A. S. (1994), "The dynamics of long-term businessto-business exchange relationships", Journal of the Academy of Marketing Science, Vol. 22, No. 2, pp. 130-145.

Day, G. S. (2003), "Creating a superior customer-relating capability", Sloan Management Review, Vol. 44, No. 3, pp. 77-82.

Day, G. S. \& Wensley, R. (1988), "Assessing advantage: a framework for diagnosing competitive superiority", Journal of Marketing, Vol. 52, No. 2, pp. 1-20.

Denison, T. \& McDonald, M. (1995), "The role of marketing: past, present and future", Journal of Marketing Practice, Vol. 1, No. 1, pp. 54-76. 
Deshpandé, R., Farley, J. U., \& Webster, F. E. (1993), "Corporate culture, customer orientation, and innovativeness", Journal of Marketing, Vol. 57, No. 1, pp. 23-37.

Deshpandé, R. \& Webster, F. E. (1989), "Organizational culture and marketing: defining the research agenda", Journal of Marketing, Vol. 53, No. 1, pp. 3-15.

Dowling, G. R. \& Uncles, M. (1997), "Do customer loyalty programs really work?" Sloan Management Review, Vol. 38, No. 4, pp. 71-83.

Doyle, P. (1989), "Building successful brands: the strategic options", Journal of Marketing, Vol. 5, No 1, pp. 77-95.

Doyle, P. (2000), Value-Based Marketing, John Wiley \& Sons, Chichester.

Dubois, A. \& Gadde, L.-E. (2002), "Systematic combining: an abductive approach to case research", Journal of Business Research, Vol. 55, No. 7, pp. 553-560.

Dwyer, F. R., Schurr, P. H., \& Oh, S. (1987), "Developing buyer-seller relationships", Journal of Marketing, Vol. 51, No. 2, pp. 11-27.

Dwyer, F. R. \& Tanner, J. F. (2002), Business Marketing, McGraw-Hill, New York.

Dyer, W. G. \& Watkins, A. (1991), "Better stories, not better constructs, to generate better theory: a rejoinder to Eisenhardt", Academy of Management Review, Vol. 16, No. 3, pp. 613619.

Easton, G. (1995), "Case research as a methodology for industrial networks: a realist apologia", Proceedings of the 11th Annual Conference on Industrial Marketing and Purchasing, September, Manchester Federal School of Business and Management, the UK

Eisenhardt, K. M. (1989), "Building theories from case study research", Academy of Management Review, Vol. 14, No. 4, pp. 532-550. 
Eisenhardt, K. M. (1991), "Better stories and better constructs: the case for rigour and comparative logic", Academy of Management Review, Vol. 16, No. 3, pp. 620-627.

Eriksson, K \& Mattson, J. (2002), "Managers' perception of relationship management in heterogeneous markets", Industrial Marketing Management, Vol. 31, No. 6, pp. 535-543.

European Journal of Marketing (2004), special issue on action research, Vol. 38, No. 3-4.

Evans, J. R. \& Berman, B. (2001), "Conceptualizing and operationalizing the business-tobusiness value chain", Industrial Marketing Management, Vol. 30, No. 2, pp. 135-148.

Ford, D. (1980), "The development of buyer-seller relationships in industrial markets", European Journal of Marketing, Vol. 14, No. 5/6, pp 339-354.

Ford, D. (1990), Understanding Business Markets, Academic Press, London.

Foss, B. \& Stone, M. (2001), Successful Customer Relationship Marketing, Kogan Page, London.

Garbarino, E. \& Johnson, M. (1999), "The different roles of satisfaction, trust and commitment in customer relationships", Journal of Marketing, Vol. 63, No. 2, pp. 70-87.

Gartner Group (2003), The Case for Knowledge Management in CRM, Stamford, Connecticut

Georgiadis, M. \& Lane, K. (2001), Customer Marketing Organization, McKinsey \& Co.

Grotenhuis, F. D. J. \& Weggeman, M. P. (2002), "Knowledge management in international mergers", Knowledge and Process Management, Vol. 9, No. 2, pp. 83-89.

Grönroos, C. (1990), "Relationship approach to marketing in service contexts: the marketing and organizational behavior interface", Journal of Business Research, Vol. 20, No. 1, pp. 3-11.

Grönroos, C. (1994), "Quo vadis, marketing? Toward a relationship marketing paradigm", Journal of Marketing Management, Vol. 10, No. 5, pp. 347-360.

Grönroos, C. (2000), Service Management and Marketing, John Wiley \& Sons, Chichester. 
Gummesson, E. (1999), Total Relationship Marketing, Butterworth-Heinemann, Oxford.

Gummesson, E. (2002), "Relationship marketing and a new economy: it's time for deprogramming", Journal of Services Marketing, Vol. 16, No. 7, pp. 585-589.

Gummesson, E., Lehtinen, U., \& Grönroos, C. (1997), "Comment on Nordic perspectives of relationship marketing", European Journal of Marketing, Vol. 31, No. 1, pp. 10-16.

Hamel, G. \& Prahalad, G. K. (1994), Competing for the Future, Harvard Business School Press, Boston, Massachusetts.

Hart, S. \& Murphy, J. (1998), Brands: The New Wealth Creators, Macmillan Press, Basingstoke.

Hunt, S. D. (2000), A General Theory of Competition - Resources, Competencies, Productivity, Economic Growth, Sage Publications, Thousand Oaks, California.

Jackson, B. B. (1985), "Build customer relationships that last", Harvard Business Review, Vol. 62, No. 6, pp. 120-128.

Joshi, A. W. \& Campbell, A. J. (2003), "Effect of environmental dynamism on relational governance in manufacturer-supplier relationships: a contingency framework and an empirical test", Journal of Academy of Marketing Science, Vol. 31, No. 2, pp. 176-188.

Kenyon, J. \& Vakola, M. (2001), "Evolving the customer relationship management paradigm in the retail industry", International Journal of Customer Relationship Management, Vol. 3, No. 4, pp. 313-322.

Klein, H. K. \& Myers, M. D. (1999), "A set of principles for conducting and evaluating interpretative field studies in information systems", Management Information Systems Quarterly, Vol. 23, No. 1, pp. 67-94.

Kothandaraman, P. \& Wilson, D. T. (2001), "The future of competition: value-creating networks", Industrial Marketing Management, Vol. 30, No. 4, pp. 379-389. 
Kotler, P. (2003), Marketing Management, Pearson Education, Upper Saddle River, New Jersey.

Kracklauer, A., Mills, D. Q., \& Seifert, D. (2003), Collaborative Customer Relationship Management, Springer-Verlag, Berlin.

Lederer, C. \& Hill, S. (2001), "See your brands through your customers' eyes", Harvard Business Review on Customer Relationship Management, Harvard Business School Press, Boston, Massachusetts, pp. 151-173.

Lee, P. M. \& Quazi, H. A. (2001), "A methodology for developing a self-assessment tool to measure quality performance in organizations", International Journal of Reliability and Quality Management, Vol. 18, No. 2, pp. 118-141.

Lewin, K. (1946), "Action research and minority problems", Journal of Social Issues, Vol. 2, No. 4, pp. 34-46.

Lincoln, Y. S. \& Guba, E. (1985), Naturalistic Inquiry. Sage Publications, Beverly Hills, California.

Lindgreen, A. (2004), "The design, implementation, and monitoring of a CRM programme: a case study", Marketing Intelligence \& Planning, Vol. 22, No. 2, pp. 160-186.

Lindgreen, A. \& Crawford, I. (1999), "Implementing, monitoring, and measuring a programme of relationship marketing", Marketing Intelligence \& Planning, Vol. 17, No. 5, pp. 141-67.

Lindgreen, A. \& Wynstra, F. (2004), "Value in business markets: What do we know? Where are we going?" Industrial Marketing Management, in press.

Masters, T. (2001), "Have we lost our way with CRM?" International Journal of Customer Relationship Management, Vol. 3, No., pp. 287-290.

McDonald, M. H. B. (2004) Marketing Plans, 5th ed., Butterwoth Heinemann, Oxford. 
McDonald, M., Rogers E., \& Woodburn, D. (2000) Key Customers - How to manage them profitably, Butterworth Heinemann, Oxford.

Michell, P., King, J., \& Reast, J. (2001), "Brand values related to industrial products", Industrial Marketing Management, Vol. 30, No. 5, pp. 415-425.

Miles, R. \& Huberman, A. M. (1994). Qualitative Data Analysis, 2nd ed., Sage Publications, Thousand Oaks, California.

Millman, A. F. \& Wilson, K. J. (1994), "From key account selling to key account management", Proceedings of the 10th Annual Conference on Industrial Marketing and Purchasing, September, University of Groningen, the Netherlands.

Morgan, R. M. \& Hunt, S. D. (1994), "The commitment-trust theory of relationship marketing", Journal of Marketing, Vol. 58, No. 3, pp. 20-38.

Parvatiyar, A. \& Sheth, J. N. (2000), "The domain and conceptual foundations of relationship marketing", in Sheth, J. N. \& Parvatiyar, A. (Eds.), Handbook of Relationship Marketing, Sage Publications, Thousand Oaks, California, pp. 3-38.

Payne, A. (1995), "Relationship marketing: a broadened view of marketing", in Payne, A. (Ed.), Advances in Relationship Marketing, Kogan Page, London, pp. 29-40.

Peck, H. (1995), "Building customer relationships through internal marketing: a review of an emerged field", in Payne, A. (Ed.), Advances in Relationship Marketing, Kogan Page, London, pp. 83-111.

Peppers, D. \& Rogers, M. (1997), Enterprise One to One, Bantam Doubleday Dell Publishing Group, New York.

Pine, B. J. (1993), Mass Customization, Harvard Business School Press, Boston, Massachusetts. 
Pine, B. J., Victor, B., \& Boynton, A. C. (1993), "Making mass customization work", in Pine, B. J. (Ed.), Mass Customization, Harvard Business School Press, Boston, Massachusetts.

Prahalad, C. K. \& Ramaswamy, V. (2001) "Co-opting customer competence", Harvard Business Review on Customer Relationship Management, Harvard Business School Press, Boston, Massachusetts, pp. 14-25.

Reichheld, F. F. (1996), The Loyalty Effect, Harvard Business School Press, Boston, Massachusetts.

Reichheld, F. F. \& Kenny, D. W. (1990), "The hidden advantages of customer retention", Journal of Retail Banking, Vol. 12, No. 4, pp. 19-24.

Reichheld, F. F. \& Sasser, W. E. Jr. (1990), "Zero defections: quality comes to services", Harvard Business Review, Vol. 68, No. 5, pp. 105-111.

Reinartz, T. J., \& Kumar, V. (2002), "The mismanagement of customer loyalty", Harvard Business Review, Vol. 80, No. 7, pp. 86-94.

Rigby, D. K., Reichheld, F. F., \& Schefter, P. (2002), "Avoid the four perils of CRM", Harvard Business Review, Vol. 80, No. 2, pp. 101-109.

Ryals, L. \& Knox, S. (2001), "Cross-functional issues in the implementation of relationship marketing through customer relationship management", European Management Journal, Vol. 19, No. 5, pp. 534-542.

Sawhney, M. (2001), "Don't homogenize, synchronize", Harvard Business Review on Customer Relationship Management, Harvard Business School Press, Boston, Massachusetts, pp. 85104.

Sheth, J. N. \& Parvatiyar, A. (Eds.) (2000) Handbook of Relationship Marketing, Sage Publications, Thousand Oaks, California. 
Sheth, J. \& Parvatiyar, A. (2002), "Evolving relationship marketing into a discipline", Journal of Relationship Marketing, Vol. 1, No. 1, pp. 3-16.

Sheth, J., Sisodia, R., \& Sharma, A. (2000), "The antecedents and consequences of customercentric marketing", Journal of the Academy of Marketing Science, Vol. 28, No. 1, pp. 55-66.

Sinkula, J. M., Baker, W. E., \& Noordewier, T. (1997), "A framework for market-based organizational learning: linking values, knowledge and behavior", Journal of the Academy of Marketing Science, Vol. 25, No. 4, pp. 305-318.

Strauss, A. \& Corbin, J. (1998), Basics of Qualitative Research, 2nd ed., Sage Publications, Newburry Park, Connecticut.

Tapscott, R. \& Caston, A. (1993), Paradigm Shift, McGraw-Hill, New York.

Tellefsen, T. \& Thomas, G. P. (2005), "The antecedents and consequences of organizational and personal commitment in business service relationships", Industrial Marketing Management, Vol. 34, No. 1, pp. 23-37.

Tzokas, N. \& Saren, M. (2004), "Competitive advantage, knowledge and relationship marketing: where, what and how?" Journal of Business and Industrial Marketing, Vol. 19, No. 2, pp. $124-135$.

Ulaga, W. (2003), "Capturing value creation in business relationships: a customer perspective", Industrial Marketing Management, Vol. 32, No. 8, pp. 677-693.

Webster, F. E. Jr. (1992), "The changing role of marketing in the corporation", Journal of Marketing, Vol. 56, No. 4, pp. 1-17.

Webster, F. E. Jr. (1994), Market-Driven Management, John Wiley \& Sons, New York, NY. Weick, K. E. (1979), The Social Psychology of Organizing, 2nd ed., Random House, New York, NY. 
Wilson, H., Daniel, E., \& McDonald, M. (2002), "Factors for success in customer relationship management (CRM) systems", Journal of Marketing Management, Vol. 18, No. 2, pp. 193219.

Woodcock, N., Stone, M., \& Foss, B. (2003), The Customer Management Scorecard, Kogan Page, London.

Yin, R. K. (1994) Case Study Research, 2nd ed., Sage Publications, Thousand Oaks, California.

Zablah, A. R., Bellenger, D. N., \& Johnston, W. J. (2004a), "Customer relationship management implementation gaps", Journal of Personal Selling \& Sales Management, Vol. 24, No. 4, pp. 279-295.

Zablah, A. R., Bellenger, D. N., and Johnston, W. J. (2004b), "An evaluation of divergent perspectives on customer relationship management: towards a common understanding of an emerging phenomen", Industrial Marketing Management, Vol. 33, No. 6, pp. 475-489.

Zikmund, W. G., McLeod, R. Jr., \& Gilbert, F. W. (2003), Customer Relationship Management, John Wiley \& Sons, New York. 

level of elements

3. Rank remaining elements systematically

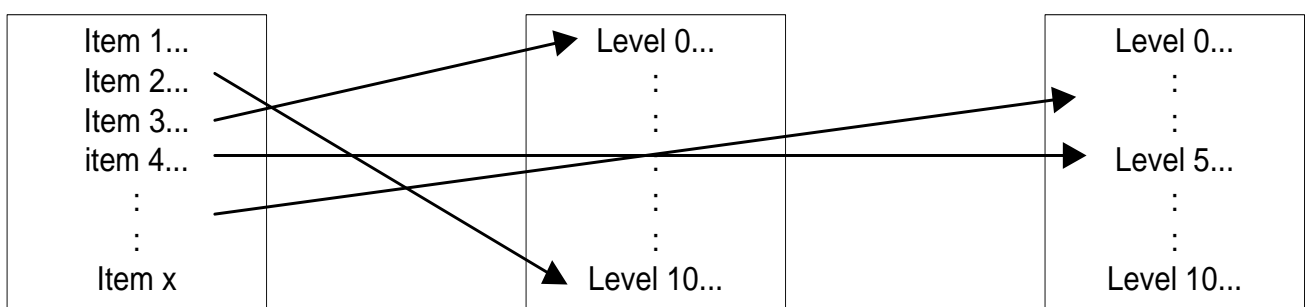

Figure 1. Stepwise approach to the assessment-tool development of relationshipmanagement elements 
Table 1. Comparison of main components of major schools of relationship marketing versus transaction marketing

\begin{tabular}{|c|c|c|c|c|}
\hline Key component & $\begin{array}{l}\text { Transaction } \\
\text { marketing }\end{array}$ & IMP group & Nordic school & $\begin{array}{l}\text { Anglo- } \\
\text { Australian } \\
\text { approach }\end{array}$ \\
\hline Basis & Exchange 4Ps & $\begin{array}{l}\text { Relationship } \\
\text { between firms }\end{array}$ & Service & $\begin{array}{l}\text { Service/quality/ } \\
\text { marketing }\end{array}$ \\
\hline Time frame & Short term & Short and long term & Long term & Long term \\
\hline Market & Single, customer & Multiple, network & $\begin{array}{l}30 \text { markets with } \\
\text { four categories }\end{array}$ & Six markets \\
\hline Organization & $\begin{array}{l}\text { Hierarchical } \\
\text { Functional }\end{array}$ & N/A & $\begin{array}{l}\text { Functional and cross } \\
\text { functional }\end{array}$ & $\begin{array}{l}\text { Cross functional } \\
\text { Process based }\end{array}$ \\
\hline Basis of exchange & Price & $\begin{array}{l}\text { Product/service, } \\
\text { information, } \\
\text { financial, and social }\end{array}$ & $\begin{array}{l}\text { Less sensitive to } \\
\text { price }\end{array}$ & Perceived value \\
\hline $\begin{array}{l}\text { Product/quality } \\
\text { dimension }\end{array}$ & $\begin{array}{l}\text { Product/technical/ou } \\
\text { tput quality }\end{array}$ & Technological & Interaction quality & $\begin{array}{l}\text { Function of value } \\
\text { and cost of } \\
\text { ownership }\end{array}$ \\
\hline Measurement & $\begin{array}{l}\text { Revenue market } \\
\text { share }\end{array}$ & $\begin{array}{l}\text { Customer } \\
\text { profitability }\end{array}$ & $\begin{array}{l}\text { Quality, Value, } \\
\text { Customer } \\
\text { satisfaction }\end{array}$ & $\begin{array}{l}\text { Customer } \\
\text { satisfaction }\end{array}$ \\
\hline $\begin{array}{l}\text { Customer } \\
\text { information }\end{array}$ & Ad hoc & $\begin{array}{l}\text { Varies by } \\
\text { relationship stage }\end{array}$ & Individual & $\begin{array}{l}\text { Customer value and } \\
\text { retention }\end{array}$ \\
\hline Internal marketing & N/A & N/A & $\begin{array}{l}\text { Substantial strategic } \\
\text { importance }\end{array}$ & $\begin{array}{l}\text { Integral to the } \\
\text { concept }\end{array}$ \\
\hline Service & $\begin{array}{l}\text { Augmentation to } \\
\text { core product }\end{array}$ & $\begin{array}{l}\text { Close seller-buyer } \\
\text { relations }\end{array}$ & Integral to product & $\begin{array}{l}\text { Basis for } \\
\text { differentiation }\end{array}$ \\
\hline
\end{tabular}




\section{Appendix A. Relationship-management assessment tool}

\section{Element 1 Customer strategy}

Level

0

1

2

3

4

5

6

7

8

9

10

We sell our goods to customers who are willing to buy. We have no criteria in place to select customers.

We have a customer strategy to select customers. Someone in our organization is responsible for this strategy.

We define customer strategies, which are mainly focused on acquiring new customers.

We base our customer strategies primarily on the needs of prospective and existing customers, rather than on (potential) customer-lifetime value.

We analyze the lifetime value of individual customers to understand their importance to our organization. Different approaches including for example activity-based costing are used to calculate the value of individual customers.

We rank customers by their value in order to define customer segments. Customers with similar lifetime value are allocated to the same customer segment.

We set clear business objectives for each customer segment. We develop a corresponding value proposition that is consistent with these objectives including, for example, a selling and pricing strategy. In each segment customers have the same lifetime value, but are differentiated from each other by their needs.

We build and develop relationships with our most valuable customers. We continually analyze their potential, and we take actions to transform unprofitable customers into profitable ones.

We retain our most valuable customers by understanding loyalty drivers and by introducing appropriate value-adding propositions. Moreover, we know why some customers defect and how to win these customers back. We increase our customer retention by offering value-adding propositions.

We meet the specific needs of our customers, and our value propositions regularly exceed their expectations. We build unique relationships with our most valuable customers. Our customers prefer our organization to do business with rather than our direct competitors because we excel in creating value-adding opportunities. We review our customer strategy continually.

We develop excellent customer strategies, which create customer trust and commitment, and drive the growth in our profitability. We are the number one strategic supplier of our most valuable customers. In order to develop the most value-adding goods and services in the marketplace we collaborate closely with our customers to exchange knowledge.

\section{Element 2 Customer-interaction strategy}

\section{Level}

0

We provide contact details so our customers can ask for information. We interact only rarely with our customers, and this interaction is not coordinated between the different levels and functional departments in our organization.

1

We make an inventory of existing customer-touch points. We map these touch points for different processes including information/communication, transaction, distribution, and service. The characteristics of each touch point are described.

We analyze and understand customer-touch points in terms of their differences, functionalities, 
importance, costs, and the business processes behind.

5

6

8

We define a customer-interaction strategy, which is aligned with our customer strategy. This means that we serve customers through appropriate channels. Low-value customers are served through low-cost channels, for example e-mail rather than face-to-face interaction.

We base the customer-interaction strategy primarily on our customers' needs. Each interaction with a customer has a clear objective, but we do not systematically capture a record of these interactions using an information system.

\section{Element 3 Brand strategy}

Level

0

1

2 customer request. briefings.

We minimize our customers' inconveniences by developing interaction channels. This helps us to provide information, resolve problems and complaints, distribute goods and services, and make transactions possible (e.g., order entry and online payment). However, these customized interactions are still not well coordinated.

We have employees whose responsibility is to capture customer information provided by each customer interaction. Every customer contact is recorded to get more insight into this customer's preferences and needs. We know when and how our customers want to interact with us.

We track the effectiveness of our interaction channel(s), and use customer feedback for improvements. Our employees in all functional areas know how best to respond quickly to a

We coordinate and manage across all levels and functional departments in the organization each single customer interaction. We achieve consistency in customer interactions.

We review continually our customer-interaction strategy. Interaction channels are used in an effective and efficient way to avoid waste of resources.

We add value through our customer-interaction strategy. This influences our customers' behavior so that they choose our organization. All channel opportunities are developed to create channel synergy. Our customer-interaction strategy is translated into competitive advantages.

We describe the brand positioning for the goods that our business unit is producing.

We have a basic understanding, within our business unit, of our brand image and the attractiveness our goods relative to that of direct competitors. We learn this through market research (ad hoc qualitative market research).

We describe the brand positioning for our goods. This brand positioning is based on the translation/amplification of the brand positioning for our goods.

We have a good understanding, within our business unit, of our brand image among a defined customer-target group and the attractiveness our goods relative to that of direct competitors. We learn this through regular qualitative market research.

We, the management and all people in direct contact with the market, know, understand, and apply the brand positioning. This understanding is consistently deployed in communication

We translate the brand positioning into the brand promise to the customer and other targeted stakeholder groups. This promise is relevant, perceivable, and attractive to the targeted groups, and is distinctive from that of our competitors.

We develop all communications (i.e., from packaging over backing cards and TV spots to public relations campaigns) using the brand positioning. We perform regular checks relating to consistency. 
We regularly measure customers' and other targeted groups' awareness of our brand. We do this through all relevant attributes in a quantitative way. Gaps between actual and targeted brand image are identified. Our brand's relative position versus that of our competitors' brands is consistently checked.

We formulate a plan in our business unit to close the gap between actual and targeted brand image. This plan also guides the definition of our product portfolio, distribution/sales channel strategy, and market-introduction policy needed to realize the targeted brand positioning in the marketplace.

We make the brand positioning an integral part of our business plan. We have validated the plan as being effective in the marketplace in driving a profitable growth.

We have achieved maximum, benchmarked awareness of our brand promise. The brand positioning has been validated as being capable of achieving long-term profitable growth for our company.

\section{Element $4 \quad$ Value-creation strategy}

Level

0

We sell goods that meet customers' requirements. There are many competitors in the market who are able to offer the same goods at competitive prices.

We base our competition for market share mainly on the quality of our goods. The marketplace is characterized by price competition, which results in small margins.

We focus on selling the features of our goods, as well as the quality and the services that are related with those goods. We do this with a profit.

We are aware that selling goods and related services only is not enough to win valuable customers.

We use market researches and value models for gaining more insight into customer requirements.

We identify added-value opportunities by understanding our customers' specific needs and preferences. We are one of our customers' preferred and selected suppliers.

We can provide the best offering in the marketplace by excelling in specific value-adding activities.

We formulate value propositions that meet specific customers' requirements. These propositions create added-value benefits and are superior to those of our competitors. This makes it possible to apply premium prices for our goods and services.

We develop comprehensive value-adding propositions that our customers trust. These propositions are the reason why we can change from short-term transactions into long-term relationships with profitable customers. Customer value comes in many forms and is beyond the immediate value of purchased goods. Services, convenience, speed, ease of access, responsiveness, trust, integrity, and education are all part of customer value.

We dominate the market by improving our value-adding activities continuously. Customer satisfiers and dissatisfiers are tracked all the time. We seek actively opportunities to create more value by regularly analyzing the results of customer satisfaction surveys.

We are acknowledged as the leading company, and for being unique, in the market. Our profits result from creating and delivering superior, innovative solutions to our customers instead of selling generic goods and services to them. We have the expertise and knowledge of our customers' value chains to help them source, produce, and deliver effectively to their own 
customers. It is difficult, if not impossible, for our competitors to copy our capabilities.

\section{Element 5 Culture}

Level

0

1

2

3

4

5

6

7

8

9

10

We request our sales people to focus on single sales rather than on customer retention. The focus is on short-term sales targets.

We are paying more attention to goods and competitors than to customers. We lack an understanding of our customers' needs and wants.

We are aware of the necessity of a customer-focused mindset, as well as an organizational change for building relationships with our most valuable customers.

We, employees or departments, especially sales people, act in a more customer-centric way. There is hardly any internal resistance to organizational or cultural change.

We delegate clear responsibility and authority to leaders in our organization in order to realize a customer-focused culture. We request our leaders to understand the market, and to show determination. Their style and methods of managing in turn are encouraging a customer orientation, as well as our employees' service mindedness.

We focus primarily on customers and long-term relationships rather than on goods and shortterm transactions. We react quickly to customer requests and demands.

We adapt the way of working in our organization: we now anticipate rather than react to our customers' requests and demands.

We constantly try to meet customers' expectations by delivering appropriate goods and services and by solving their problems quickly. Our employees are competent to communicate in a customer-oriented way, and possess the required interaction skills.

We focus on creating value-adding opportunities for our customers. Our employees are committed and dedicated to satisfying our customers. Employees feel responsible for the end result and act with the customer in mind.

We constantly think from the customer's point of view in order to improve business performance. We emphasize on seeking new, innovative ways of working to serve our customers individually. Also, we continuously try to exceed customers' expectations and requirements.

We instill a customer-focused culture in our organization. Customer focus and commitment are parts of our corporate vision and mission. Honesty and openness characterize the way of working. We involve in an early stage our customers and suppliers in product and service development, and continue to monitor external developments.

\section{Element 6 People}

\section{Level}

We have a high employee turnover in our organization. Negative effects including lack of knowledge of customer details and loss of information are visible.

1 We understand the essence of employee satisfaction and commitment, which is correlated with customer retention.

We identify and describe different roles in our organization including competencies and accountabilities, which affect the customer's experience. This includes people in departments such as product, marketing, sales, services, finance, administration, operations, and technical support. 
We select and recruit people with the right skills and orientation in accordance with job descriptions. Appropriate leadership and customer management competencies are essential characteristics for customer-facing employees. These competencies are requirements in our job descriptions. A customer-focused mindset is part of recruiting and training programs.

We reward our employees based on their individual performance and productivity. We make customer-focused behavior a significant part of performance appraisal criteria, and ensure that incentives and rewards encourage a customer-focused behavior.

\section{Element 7 Organization}

Level

0

1 manage customers.

We ensure that our employees understand their roles and possess the basic skills and knowledge to identify our customers' needs and preferences that are of value to them.

We regularly assess the skills of our employees' to identify competency gaps. Development and training plans are implemented to enhance customer-management skills.

We require each employee to take whatever action appropriate to ensure the satisfaction of our valuable customers. A certain degree of autonomy in decision making allows our employees to

We increase the retention of our skilful employees. We seek to reinforce customer loyalty, to reduce costs of hiring and training, and to increase productivity. Our experienced employees deliver high-service quality at low costs. Our employees possess the capability to create valueadding activities for our customers.

We ensure that our employees have a sound market sensing, an ability for understanding our customers (show empathy), and a capability to establish, maintain, and enhance customer relationships by gaining their trust and respect. Our employees are able to win concessions without damaging customer relationships. Also, they have excellent skills like business and product knowledge to convince customers to select our organization.

We, our organization and our employees, are acknowledged by our customers as the most careful, knowledgeable, and skilful professionals to trade with. Our employees understand the difference between added-value and value-adding activities. Employees in our organization are our most valuable assets.

We see the functional departments in our organization as autonomous units. There is a lack of communication between departments.

We manage customer relationships only through the sales department.

We understand how the organizational structure is designed, and how this structure affects the performance of our customer management and other activities.

We introduce a number of contacts between the selling and buying parties to replace the traditional relationship between sales and purchasing departments. These contacts represent the marketing, finance, logistics, and information-technology departments.

We manage the relationship with our customers through different departments in our organization. Also, we define procedures to manage customer complaints. The accountabilities and procedures for several customer processes are written down clearly.

We ensure that functional departments collaborate to meet our customers' needs and wants. Communication between departments has been improved, but it is still not optimal. We have a dedicated key account manager to coordinate the development of our customer relationships.

We delegate the coordination and management of customer relations to middle and senior 
management. Their role is to help customer-facing employees by supporting, coaching, and providing required resources.

We adapt the organizational structure by setting up cross-functional teams. The goal is to bring the specialized knowledge of different functions and task groups together to develop goods and services that meet our customers' needs and wants.

We make sure that our employees are strong team players in cross-functional teams. Established teams have the authority to set coordinated value-adding customer strategies, and are able to maximize returns on customer information.

We are a flexible organization that supports a customer-oriented decision making, and have the flexibility to anticipate and respond to our customers' value-adding requests.

We manage consistently across different organizational levels and functional departments our customer relationships. The internal communication works seamlessly and smoothly among customer facing employees, as well as between them and the rest of the organization. Customers perceive us as a well-organized company.

\section{Element 8 Information technology}

Level

We usually work with stand-alone systems, for example database marketing. There is no structured way of working to collect and use customer data.

We set up separated information-technology systems in our organization to hold important information about our customers such as transactions information. Some data is collected on paper rather than in an information-technology system.

We determine which data is required to support customer-management processes. Such data includes historical data for customer transactions and customer contacts. This data is collected within a particular business unit using several information-technology systems. We understand how technologies will support our business processes, and have defined system requirements. We prioritize analytic needs of our organization before making major information-technology investments.

We design and build a common data store such as a data warehouse or data mart. Data fragmentation, however, still occurs.

We define in detail terms in databases to avoid differences in meanings by departments or user groups. The visibility and accessibility of customer data (obtained from a variety of customertouch points) among customer-facing employees and other employees have been increased, but integration of customer-contact channels is still not fully realized.

We avoid data fragmentation problems by consolidating all customer information collected from various customer-contact channels: face-to-face such as sales representatives, fax, mail, telephone, E-mail, and Websites to allow E-technology applications such as online billing, order entry, and configuration. E-technology also makes it possible for our customers to validate or refresh supply chain data or customer data. They can do this themselves, and more frequently and accurately.

We integrate front- and back-office systems. Front-office applications such as portals pull information from the back-office system such as enterprise resource planning systems. Data is sourced from our customers' legacy systems and external data sources.

We realize the integration of customer-contact channels. It allows the sharing and usage of information about our customers, which support activities such as sales force automation, customer contact, campaign management, customer-service management, and order and supplychain management. Before analysis, customer data must be cleaned (e.g., eliminating duplicated 
or irrelevant data), grouped, and transformed into a consistent and usable format. Someone in the organization is given the responsibility for the quality and the management of data within the context of a single business function or process. The quality of the data is determined by the following criteria: accuracy, consistency, reliability, accessibility, and completeness.

We develop insights into our customers by analyzing customer and market data extracted from our databases. Information-technology system tools allow our organization to analyze and look for patterns in customer data. These information-technology system tools, for example data mining, are able to identify profitable customers and their characteristics; predict customerbuying behavior (by purchase analysis, interaction/channel analysis, customer-response analysis, and market analysis); evaluate marketing-campaign effectiveness; provide opportunities for cross and up selling; estimate customers' potential; and reveal factors that cause customers to remain loyal to our organization.

We use innovative technologies including, for example mobile devices, to update customer data in real time to provide each system and channel with the most recent customer information. This way of working reduces the time to market. Our selection of technologies is validated by a customer-oriented process.

We achieve an integrated, cross-functional, multiple-channel (contact channel) view of our customers. We achieve this by the integration of consistent customer data and applications. This comprehensive customer intelligence allows us to manage each customer relationship efficiently and effectively, and to grow our business. The integration of information systems is extended to our key partners and suppliers.

\section{Element 9 Relationship-management processes}

Level

We identify relationship-management processes such as contact planning, complaint management, customer segmentation, order processing, and service management.

1

We map and document relationship-management processes for each stage of the customer lifecycle. In our organization there is a focus on managing and improving the performance of relationship-management processes.

We ensure that we fully understand present processes before implementing improvements to these processes. The intent of process improvement is to minimize variation around high performance levels, which is based on customer values. Key performance indicators are linked to relationship-management processes such as retention rate, share of wallet, customer-lifetime value, and customer satisfaction.

We determine standards and criteria of measurement for each relationship-management process. By setting concrete and measurable process targets, we lay the foundation for continuous improvement.

We capture customer feedback regarding goods and services by conducting customer satisfaction surveys to identify and eliminate process failures. Key performance indicators of relationshipmanagement processes are measured and analyzed. However, the reviewing of such processes is not structured.

We implement tools or framework for continuous improvement of relationship-management processes. These relationship-management processes support added-value activities.

We measure the performance of channels and campaigns of value-adding projects. We do this next to the measuring of key performance indicators. We evaluate each campaign to apply the learning in the development of new activities. The effectiveness of employees related to relationship-management processes is measured as well. 
We realize strong process improvement by eliminating activities that do not create an output, which is valued by the customer; consolidating other partially redundant customer activities; and learning from each other within our organization how to improve customer activities.

8

9

10

We review and manage in a routine structure the performance of our relationship-management processes. The performance of these relationship-management processes is judged on the basis of the value-adding criteria. The strategic and business processes produce clear objectives for improvements, and have a strong focus on customer satisfaction by enhancing the flexibility of customer-relationship processes.

We make customer-relationship process improvements a closed-loop system in our quality management. This is required for continuous improvement.

We have reached maximum relationship-management processes. These processes are characterized by their value-adding capability. The results of customer satisfaction surveys show that our customers are completely satisfied. Our relationship-management processes are the benchmark in the industry. Continuous improvement is part of the day-to-day analysis and activities.

\section{Element 10 Knowledge management and learning}

Level

0

1

2

3

We are ignorant about the relevance of knowledge management.

We understand the role and importance of knowledge management in terms of developing business strategies, goods, and services. Some knowledge is captured relating to customer behavior and knowledge of customers relative to product use.

We identify sources that generate data, information, and knowledge. However, there is no structured way to manage and leverage knowledge.

We map the process of knowledge creation; the knowledge is about business markets, business processes, customers, and competitors. Incentives like motivation, reward, and recognition are provided to encourage the leveraging and generating of knowledge.

We define procedures to instill knowledge into our organization. We extend across the organization a network to connect people to each other, linking 'knowledge seekers' with 'knowledge providers'. This enables collaboration, application of organizational learning, and sharing of best practices.

We ensure that our employees increase their knowledge through continuous learning. This is realized through participation in training programs.

We facilitate knowledge management using information-technology systems. This allows managing and sharing of valuable knowledge across the organization. Implicit knowledge is transferred into explicit knowledge and vice versa. We possess the knowledge to create valueadding activities for our customers.

We apply and re-use knowledge to accelerate learning processes. Shorter time to market and reduced integral costs are one of the results of well-managed knowledge.

We create sustainable competitive advantage by creating knowledge assets, which contribute to improvements of competences within our organization. Knowledge is regularly reviewed for validity, and is updated when it is necessary.

We selectively benchmark organizations and participate in forums for development of new knowledge. Knowledge management is a part of our organization's culture.

We base our strategies on knowledge creation and management. Creating and exploiting 
knowledge as core strength of our organization allow us to set the pace of change in technologies, goods, applications, and marketplaces. 